\title{
KEBIJAKAN PENEGAKAN HUKUM PIDANA TERHADAP TINDAK PIDANA PERJUDIAN
}

\author{
Said Munawar \\ Fakultas Hukum Universitas Widya Mataram \\ Ndalem Mangkubumen KT III/237 Yogyakarta 55132, Indonesia \\ said_munawar15@yahoo.com
}

\begin{abstract}
Gambling is a social disease. In positive law, gambling is a criminal offense, namely the issuance of Law Number 7 of 1974 concerning Control of Gambling and its implementation is regulated in detail as stated in Republic of Indonesia Government Regulation Number 9 of 1981. Explained that law as a social policy tool of social engeneerings.

This paper using normative juridical research method, it concluded: First, criminal law in Indonesia can be used to overcome gambling crime, in the sense of its discipline, namely: "Unlicensed elements" It means that there is no element without permission attached to the law against acts criminal gambling, or if there is permission from an official or agency that has the right to give permission, all actions in the formulation are no longer or remove the nature of being unlawful, therefore they cannot be convicted. This provision opens up opportunities for legalization of gambling. Because gambling is only illegal or prohibited if done without permission. So the crime of gambling in its form is formal offense. Second, the applicative policy of criminal law in overcoming gambling crime, judges do not have the freedom to determine the types of crimes that are suitable for criminal offenders and must apply or stipulate provisions on criminal threats provided in the legislation.
\end{abstract}

Keywords :Ciminal offense, Gambling, Law Enforcement

\begin{abstract}
Abstrak
Perjudian merupakan penyakit sosial. Di dalam hukum positif, perbuatan judi sebagai tindak pidana kejahatan yakni dengan diterbitkannya Undang-Undang Nomor 7 Tahun 1974 tentang Penertiban Perjudian dan pelaksanaannya diatur secara detail tertuang pada Peraturan Pemerintah RI Nomor 9 Tahun 1981. Dijelaskan bahwa hukum sebagai alat kebijakan sosial, Law as a tool of social engeneerings. Penulisan ini menggunakan metode penelitian yuridis normatif, maka dapat disimpulkan: Pertama, kebijakan kriminal hukum pidana di Indonesia sudah dapat digunakan untuk mengatasi tindak pidana perjudian, dalam arti penertibannya, yaitu : “Unsur tanpa izin"artinya tiadanya unsur tanpa izin melekat sifat melawan hukum terhadap tindak pidana perjudian itu, atau jika ada izin dari pejabat atau instansi yang berhak memberi izin, semua perbuatan dalam rumusan tersebut tidak lagi atau hapus sifat melawan hukumnya, oleh karena itu tidak dapat dipidana. Ketentuan ini membuka peluang adanya legalisasi perjudian sebab permainan judi hanya bersifat melawan hukum atau menjadi larangan apabila dilakukan tanpa izin.Jadi tindak pidana perjudian dalam wujudnya adalah delik formil.Kedua, kebijakan aplikatif hukum pidana dalam menanggulangi tindak pidana perjudian, hakim tidak memiliki kebebasan dalam menentukan jenis-jenis pidana yang sesuai untuk pelaku tindak pidana dan harus menerapkan atau menetapkan ketentuan ancaman pidana yang telah disediakan dalam peraturan perundang-undangan.
\end{abstract}

Kata kunci: Penegakan Hukum, Perjudian, Tindak Pidana.

\section{A. Pendahuluan}

Upaya pembangunan hukum dan pembaharuan hukum harus dilakukan secara terarah dan terpadu.Kodifikasi dan unifikasi bidang-bidang hukum dan 
penyusunan perundang-undangan baru sangat dibutuhkan.Instrumen hukum dalam bentuk perundang-undangan ini sangat diperlukan untuk mendukung pembangunan di berbagai bidang sesuai dengan tuntutan pembangunan serta tingkat kesadaran hukum serta pandangan masyarakat tentang penilaian suatu tingkah laku. ${ }^{1}$

Pembangunan dalam bidang hukum khususnya pembangunan hukum pidana, tidak hanya mencakup pembangunan yang bersifat struktural, yakni pembangunan lembaga-lembaga hukum yang bergerak dalam suatu mekanisme, tetapi harus juga mencakup pembanguan substansial berupa produk-produk yang merupakan hasil suatu sistem hukum dalam bentuk peraturan hukum pidana dan yang bersifat kultural, yakni sikap-sikap dan nilai-nilai yang mempengaruhi berlakunya sistem hukum. ${ }^{2}$

Hukum pidana seringkali digunakan untuk menyelesaikan masalah patologi sosial khususnya dalam penanggulangan kejahatan.Khususnya masalah perjudian sebagai salah satu bentuk penyakit masyarakat, satu bentuk patologi sosial. ${ }^{3}$ Penegakan hukum pidana untuk menanggulangi perjudian sebagai perilaku yang menyimpang harus terus dilakukan.Hal ini sangat beralasan karena perjudian merupakan ancaman yang nyata terhadap norma-norma sosial yang dapat menimbulkan ketegangan individual maupun ketegangan-ketegangan sosial.Perjudian merupakan ancaman riil maupun potensiil bagi berlangsungnya ketertiban sosial. $^{4}$

Perjudian dapat menjadi penghambat pembangunan nasional yang beraspek materiel-spiritual dan mendidik orang untuk mencari nafkah dengan tidak sewajarnya dan membentuk watak "pemalas".Sedangkan pembangunan membutuhkan individu yang giat bekerja keras dan bermental kuat. ${ }^{5}$ Sangat beralasan kemudian judi harus segera dicarikan cara dansolusi yang rasional untuk suatu pemecahannya. Karena sudah jelas judi merupakan problema sosial

\footnotetext{
${ }^{1}$ Romli Atmasasmita, 2007, Teori dan Kapita Selekta Kriminologi, Refika Aditama, hal. 20.

${ }^{2}$ Nyoman Serikat Putra Jaya, 2005. Relevansi hukum pidana adat dalam pembaharuan hukum pidana nasional.Bandung: Citra Aditya Bakti, hal. 67.

${ }^{3}$ Kartini Kartono, 2005. Patologi Sosial. Jakarta : Raja Grafindo Persada, hal. 12.

${ }^{4}$ Muladi dan Barda Nawawi Arief, 1998.Teori-Teori dan Kebijakan Pidana, Cet. II, Bandung : Penerbit Alumni, hal. 25.

${ }^{5}$ Simandjuntak, B, 1980. Pengantar Kriminologi dan Patologi Sosial, Bandung : Tarsito, hal. 30.
} 
yang dapat mengganggu fungsi sosial dari masyarakat.Salah satu usaha rasional yang digunakan untuk menanggulangi perjudian adalah dengan pendekatan kebijakan hukum pidana.

Penggunaan hukum pidana ini sesuai dengan fungsi hukum sebagai social control atau pengendalian sosial yaitu suatu proses yang telah direncanakan lebih dahulu dan bertujuan untuk menganjurkan, mengajak, menyuruh atau bahkan memaksa anggota-anggota masyarakat agar mematuhi norma-norma hukum atautata tertib hukum yang sedang berlaku. ${ }^{6}$

Disamping itu hukum pidana juga dapat dipakai sebagai sarana untuk merubah atau membentuk masyarakat sesuai dengan bentuk masyarakat yang dicita-citakan; fungsi demikian itu oleh Roscoe Pound dinamakan sebagai fungsi Law as a tool of social engineerings atau hukum sebagai alat rekayasa sosial. ${ }^{7}$

Berdasarkan dari pemahaman latar belakang masalah diatas maka permasalahan yang akan dikaji adalah, pertama, bagaimanakah kebijakan kriminal dalam menanggulangi tindak pidana perjudian. Kedua, bagaimanakah kebijakan aplikatif hukum pidana dalam menanggulangitindak pidana perjudian di Indonesia.

\section{B. Telaah Konsep}

\section{Definisi Perjudian dalam Norma Agama dan Norma Sosial}

Perjudian mempunyai dampak yang negatif merugikan moral dan mental masyarakat terutama generasi muda.Judi adalah merupakan problem sosial yang sulit di tanggulangi karena adanya judi dengan berbagai implikasinya sudah ada sejak adanya peradaban manusia.

Dalam Ensiklopedia Indonesia judi diartikan sebagai suatu kegiatan pertaruhan untuk memperoleh keuntungan dari hasil suatu pertandingan permainan atau kejadian yang hasilnya tidak dapat diduga sebelumnya. Sedangkan Dra. Kartini Kartono mengartikan judi adalah pertaruhan dengan sengaja, yaitu mempertaruhkan satu nilai atau sesuatu yang dianggap bernilai,

${ }^{6}$ Ronny Hanitijo Soemitro, 1985. Beberapa Masalah Dalam Studi Hukum dan Masyarakat.Bandung : Remaja Karya, hal. 54.

${ }^{7}$ Ibid, hal. 55 . 
dengan menyadari adanya risiko dan harapan-harapan tertentu pada peristiwaperistiwa permainan, pertandingan pertandingan, perlombaan dan kejadiankejadian yang tidak ataupun belum pasti hasilnya.

a) Perjudian Ditinjau Dari Norma Agama

Negara Kesatuan RI yang berdasarkan Pancasila dan UUD 1945 adalah bukan merupakan negara sekuler, yang berdasarkan atas suatu agama tertentu melainkan berdasarkan Ketuhanan Yang Maha Esa (sila pertama Pancasila jo Pasal 29 ayat (1) UUD 1945). Dikatakan bahwa Negara Kesatuan RI bukan negara sekuler, karena dalam penyelenggaraan pemerintahan negara RI tidak memisahkan sama sekali urusan kenegaraan dengan urusan keagamaan. Agama merupakan sumber kepribadian bangsa sebagai landasan moral dan etis yang terimplikasi dalam asas-asas sebagai sumber hukum perundang-undangan, dan dalam perwujudannya sebagai undang-undang di dalam pelaksanaannya harus dijalankan dan ditaati.Hal itu bertujuan agar perbuatan atau perilaku masyarakat tidak menyimpang dari norma-norma yang ada di dalam agama tersebut. Kenyataan dalam pergaulan hidup di masyarakat seseorang tidak jarang menyimpang dari norma agama, hal itu disebabkan oleh kurangnya iman terhadap seseorang yang akhirnya dapat menjurus kepada perbuatan-perbuatan yang dilarang oleh agama.

Tanggapan masyarakat berbeda-beda terhadap praktek perjudian, namun perjudian apapun bentuknya dan namanya hakekatnya adalah bertentangan dengan agama. Ditinjau dari segi apapun juga, maka judi tersebut merupakan penyakit masyarakat yang lebih banyak mudharotnya dibandingkan dengan kemanfaatannya, khususnya agama Islam yang melarang tentang perjudian dalam segala bentuknya sebab merusak jiwa, merusak badan, merusak rumah tangga dan merusak masyarakat.

Menurut Syamsudin Adi Dzahabiyang dimaksud dengan judi ialah, "Suatu permainan atau undian dengan memakai taruhan uang maupun lainnya masingmasing dari keduanya ada yang menang ada yang kalah (untung dan dirugikan)". Lebih lanjut dinyatakan:

${ }^{8}$ Syamsuddin Adz-Dzahabi. 1992. 75 Dosa Besar. Surabaya: Media Idaman, hal. 78. 
Allah SWT telah melarang judi seperti firman-Nya yang terdapat di dalamKitab Suci Al-Qur'an surat Al-Maidah ayat 90 yang menyatakan?:

"Haiorang-orang yang beriman, sesunggubnya (meminum) khamar,berjudi (berkorban untuk berbala), mengundi nasib dengan panah-panah adalah perbuatan keji termasuk perbuatan setan maka jaubilah perbuatan-perbuatan itu, agar mendapat keberuntungan”.

Di samping itu juga dalam kitab suci Al-Qur'an surat Al-Maidah ayat 91 yang menyatakan ${ }^{10}$ :

"Sesunggubnya setan bermaksud bendak menimbulkan permusuban dan kebencian diantara kamu antara meminum khamar dan berjudi itu, dan menghalangi kamu untuk. mengingat Allah dan Sholat, maka berhentilah kamu dari mengerjakan pekerjaan itu".

Sudah jelas bahwa dari segi norma agama dalam hal ini agama Islam melarang umatnya bermain judi kemudian agama-agama lainnya pun juga demikian sebab dari adanya permainan judi tersebut menyebabkan permusuhan antara sesama umat manusia yaitu saling dendam dan iri hati dan dari adanya perbuatan judi tersebut akan membuat harta benda menjadi mubazir, tidak halal. Harta benda yang dihasilkan dari perjudian ini termasuk cara yang terlarang, dan apabila harta dimakan berarti ia memakan barang haram, bila dipakai untuk usaha berarti juga menggunakan modal yang dilarang oleh Islam dan jika hal tersebut dibelanjakan di jalan Allah, maka Allah juga tidak akan menerimanya.

Nampak jelas bahwa perjudian ini tergolong sebagai perbuatan dosa besar sebab bertolak dari sanalah seperangkat perbuatan dosa dapat timbul. Misalnya, timbul rasa benci antara yang kalah dan yang menang, pertengkaran dan berontak di dalam rumah tangganya akibat kalah bahkan banyak juga terjadi pencurian, pembalakan dan perampokan yang disebabkan oleh perkara yang sama. Oleh karenanya Islam melarang perbuatan judi.

b) Perjudian Ditinjau Dari Norma Sosial Yang Lain

Banyak negara melarang perjudian dengan memberi sanksi keras, disebabkan oleh pengaruh buruk yang ditimbulkan oleh perjudian antara lain berupa kriminalitas, kecanduan narkotik dan prostitusi atau pelacuran.

${ }^{9}$ Surat Al-Maidah ayat 90.

${ }^{10}$ Surat Al-Maidah ayat 91. 
Ditinjau dari segi moral judi yang bersifat untung-untungan disamping dapat mengganggu kreativitas kerja juga mengganggu moralitas kehidupan keluarga, masyarakat. Karena spekulasi yang berlebih-lebihan, sementara cara berpikir irasional akan menyuburkan kebudayaan mistik suatu hal yang mengarah kepada kemusyrikan sedangkan pembangunan membutuhkan mentalitas yang progresif, sehingga masyarakat yang tingkat pendidikannya relatif rendah sering menjadi korban dari keganasan judi ini.

Pendidikan bangsa bermaksud selain mencerdaskan kehidupan masyarakat juga bertujuan meningkatkan budi pekerti dan akhlak yang luhur oleh karena keadaan sosial yang dihasilkan oleh perjudian tersebut sangat merusak kemungkinan tercapainya tujuan pendidikan dan pembangunan.

\section{Perjudian dalam Hukum Positif Indonesia}

Dalam rangka mengkaji kebijakan formulasi sebagai upaya penanggulangan tindak pidana perjudian sebagaimana diatur pada Undang-Undang Nomor 7 Tahun 1974 Penertiban Perjudian sebagai peraturan atau ketentuan yang menyempurnakan KUHP. Maka terlebih dahulu akan dibahas tentang kebijakan kriminalisasi.

Seperti yang telah dikemukakan di atas lahirnya Undang-Undang Nomor 7 Tahun 1974 tentang Penertiban Perjudian merupakan ketentuan atau peraturan perundang-undangan yang menetapkan dan merubah beberapa ketentuan yang ada dalam KUHP. Adapun perumusan dan penetapan ketentuan sanksi pidana oleh pembentuk undang-undang diatur dalam Pasal 303 dan 303 bis, yang kedua pasal tersebut adalah kejahatan.

Kejahatan yang dimaksudkan di atas dirumuskan dalam Pasal 303 KUHP yang selengkapnya adalah sebagai berikut:

1) Diancam dengan pidana penjara paling lama sepulub tahun atau pidana denda paling banyak dua pulub lima juta rupiah, barang siapatanpa mendapat izin:

(1) dengan sengaja menawarkan atau memeberikan kesempatan untuk permainan judi dan menjadikannya sebagai pencaharian, atau dengan sengaja turut serta dalam suatu kegiatan usaba itu;

(2) dengan sengaja menawarkan atau memberi kesempatan kepada khalayak umum untuk bermain judi atau dengan sengaja turut serta dalam kegiatan usaha itu, dengan tidak, peduli apakah untuk menggunakan kesempatan adanya sesuatu syarat atau dipenubinya sesuatu tata cara;

(3) menjadikan turut serta pada permainan judi sebagai pencabarian. 
2) kalau yang bersalah melakukan kejahatan tersebut dalam menjalankan pencahariannya, maka dapat dicabut baknya untuk menjalankan pencabarian itu.

3) Yang disebut dengan permainan judi adalah tiap-tiap permainan, dimana pada umumnya kemungkinan mendapat untung bergantung pada keberuntungan belaka, juga karena pemainnya lebih terlatih atau lebih mabir. Di situ termasuk segala pertaruban tentang keputusan perlombaan atau permainan lain-lainnya yang tidak diadakan antara mereka yang turut berlomba atau bermain, demikian juga segala pertaruban lainnya.

Adapun kejahatan mengenai perjudian yang dimaksudkan tersebut dirumuskan dalam Pasal 303 bis yang rumusannya sebagai berikut:

a. Diancam dengan pidana penjara paling lama empat tabun atau pidana denda paling banyak sepulub juta rupiah;

(1) barang siapa menggunakan kesempatan main judi, yang diadakan dengan melanggar ketentuan Pasal 303;

(2) barang siapa ikut serta main judi di jalan umum atau dipinggir jalan umum atau di tempat yang dapat dikunjungi umum, kecuali jika ada iz̨in dari penguasa yang berwenang yang telah memberi izin untuk mengadakan perjudian itu.

b. jika ketika melakukan pelanggaran belum lewat dua tabun sejak ada pemidanaan yang menjadi tetap karena salah satu dari pelanggaran ini, dapat dikenakan pidana penjara paling lama enam tabun atau pidana denda paling banyak. lima belas juta rupiah.

Untuk melakukan kriminalisasi suatu perbuatan biasanya dilakukan melalui suatu proses yang diawali dengan penetapan suatu perbuatan yang dilakukan oleh seseorang atau dipersamakan dengan orang, yang oleh undang-undang dinyatakan sebagai perbuatan yang dilarang dan diancam dengan sanksi. Proses ini berakhir dengan terbentuknya undang-undang di mana perbuatan diancam dengan suatu sanksi yang berupa pidana.

Membicarakan kebijakan kriminalisasi yang terdapat pada Undang-Undang No. 7 Tahun 1974 Tentang Penertiban Perjudian lebih lanjut akan diuraikan mengenai, ruang lingkup perbuatan yang merupakan delik perjudian.

\section{Ruang Lingkup Tindak Pidana Perjudian}

Rumusan kejahatan Pasal 303 KUHP tersebut di atas, ada lima macam kejahatan mengenai hal perjudian (bazardspel), dimuat dalam ayat (1) sedangkan ayat (2) memuat tentang dasar pemberatan pidana, dan ayat (3) menerangkan tentang pengertian permainan judi yang dimaksudkan oleh ayat (1). Lima macam kejahatan mengenai perjudian tersebut di atas mengandung unsur tanpa izin. Tanpa unsur tanpa izin inilah melekat sifat melawan bukum dari semua perbuatan dalam lima macam kejahatan 
mengenai perjudian itu. Artinya tiadanya unsur tanpa izin, atau jika ada izin dari pejabat atau instansi yang berhak memberi izin, semua perbuatan dalam rumusan tersebut tidak lagi sifat melawan hukum perbuatan oleh karena itu tidak dipidana.Dimasukkannya unsur tanpa izin ini oleh pembentuk undang-undang dikarenakan perjudian terkandung suatu maksud agar pemerintah atau pejabat pemerintah tertentu tetap dapat melakukan pengawasan dan pengaturan tentang permainan judi.

Pada ayat (2) Pasal 303 dikatakan diancam pidana pencabutan hak menjalankan pencaharian bagi barang siapa yang melakukan lima macam kejahatan mengenai perjudian tersebut di atas dalam menjalankan pencahariannya. Pada ayat (3) diterangkan tentang arti perjudian, yakni tiap-tiap permainan di mana pada umumnya kemungkinan mendapat untung bergantung pada peruntungan belaka, dan juga karena permainannya terlatih atau lebih mahir. Dari rumusan di atas sebenarnya ada bentuk perjudian, yakni sebagai berikut:

a. Suatu permainan yang kemungkinan mendapat untung bergantung pada peruntungan atau nasib belaka. Pada macam perjudian ini, menang atau kalah dalam arti mendapat untung atau rugi hanyalah bergantung pada keberuntungan saja, atau secara kebetulan saja. Misalnya dalam permainan judi dengan menggunakan dadu.

b. Permainan yang kemungkinan mendapat untung atau kemenangan sedikit atau banyak bergantung pada kemahiran atau keterlatihan si pembuat. Misalnya permainan melempar bola, permainan dengan memanah, bermain bridge, atau domino.

Dua pengertian perjudian di atas, diperluas juga pada dua macam pertaruhan, yaitu:

a. Segala bentuk pertaruhan tentang keputusan perlombaan lainnya yang tidak diadakan antara mereka yang berlomba atau bermain. Misalnya dua orang bertaruh tentang suatu pertandingan sepak bola antara dua kesebelasan, di mana yang satu bertaruh dengan menebak satu kesebelasan sebagai pemenangnya dan yang satu pada kesebelasan lainnya.

b. Segala bentuk pertaruhan lainnya yang tidak ditentukan dengan kalimat yang tidak menentukan bentuk pertaruhan secara limitatif, maka segala bentuk 
pertaruhan dengan cara bagaimana pun dan dalam segala hal manapun adalah termasuk perjudian. Seperti beberapa permainan kuis untuk mendapatkan hadiah yang ditayangkan pada televisi termasuk juga pengertian perjudian menurut pasal ini. Tetapi permainan kuis tidak termasuk permainan judi yang dilarang, apabila terlebih dahulu mendapatkan izin dari instansi atau pejabat yang berwenang.

\section{Metode Penelitian}

Tipe dari penelitian ini adalah penelitian hukum normatif.Menurut Soerjono Soekanto dan Sri Mamudji, ${ }^{11}$ pada penelitian hukum normatif, bahan pustaka adalah merupakan data dasar yang dalam ilmu penelitian digolongkan sebagai data sekunder.

\section{Pembahasan}

\section{Kebijakan Kriminal dalam Menanggulangi Tindak Pidana Perjudian}

Pasal 303 ayat (3) KUHP mengartikan judi adalah tiap-tiap permainan yang mendasarkan pengharapan untuk menang, pada umumnya bergantung kepada untung-untungan saja, dan juga kalau pengharapan itu jadi bertambah besar karena kepintaran dan kebiasaan permainan. Termasuk juga main judi adalah pertaruhan tentang keputusan perlombaan atau permainan lain, yang tidak diadakan oleh mereka yang turut berlomba atau bermain, demikian juga segala permainan lain-lainnya. Lebih lanjut Pasal 303 ayat (3) di atas secara detil dijelaskan dalam penjelasan Pasal 1 Peraturan Pemerintah RI Nomor 9 Tahun 1981 tentang Pelaksanaan Undang-Undang Nomor 7 Tahun 1974 tentang Penertiban Perjudian. Antara lain adalah rolet, poker (main kartu), hwa-hwe, nalo, adu ayam, adu sapi, adu kerbau, adu kambing, pacuan kuda dan karapan sapi.

Dalam peristiwa tertentu seperti adu ayam, karapan sapi dan sebagainya itu tidak termasuk perjudian apabila berkaitan dengan upacara keagamaan/adatistiadat/kebiasaan, dan sepanjang kebiasaan itu tidak merupakan perjudian.

${ }^{11}$ Soerjono Soekanto \& Sri Mamudji, 1985.Penelitian bukum normatif: suatu tinjauan singkat. Jakarta : Rajawali, hal. 22. 
Pada umumnya masyarakat Indonesia berjudi dengan menggunakan kartu remi, domino, rolet, dadu, sabung ayam, togel(toto gelap), dan masih banyak yang lain. Pada saat piala dunia, baik di kampung, kantor dan cafe, baik tua maupun muda, sibuk bertaruh dengan menjagokan tim favoritnya masingmasing. Sehingga benar kata orang... "kalau orang berotak judi, segala hal dapat dijadikean sarana berjudi".

Dalam mewujudkan tertib sosial, negara menetapkan dan mengesahkan peraturan perundang-undangan untuk mengatur masyarakat.Peraturan-peraturan itu mempunyai sanksi hukum yang sifatnya memaksa.Artinya bila peraturan itu sampai dilanggar maka kepada pelanggarnya dapat dikenakan sanksi (hukuman). Jenis hukuman yang akan dikenakan terhadap si pelanggar akan sangat tergantung pada macamnya peraturan yang dilanggar. Pada prinsipnya setiap peraturan mengandung sifat paksaan artinya orang-orang yang melanggar ketentuan tersebut akan dikenai sanksi terhadap pelanggaran tersebut.

Penegakan hukum pada hakikatnya merupakan bagian dari politik kriminal yang pada hakikatnya menjadi bagian integral dari kebijakan sosial (social policy), Kemudian kebijakan ini diimplementasikan ke dalam sistem peradilan pidana (criminal justice system), menurut Muladi, sistem peradilan pidana mempunyai dimensi fungsional ganda. Di satu pihak berfungsi sebagai sarana masyarakat untuk menahan dan mengendalikan kejahatan pada tingkatan tertentu (crime containment system), dilain pihak sistem peradilan pidana juga berfungsi untuk pencegahan sekunder (secondary prevention) yaitu mencoba mengurangi kriminalitas dikalangan mereka yang pernah melakukan tindak pidana dan mereka yang bermaksud melakukan kejahatan melalui proses deteksi, pemidanaan dan pelaksanaan pidana. ${ }^{12}$

Sistem peradilan pidana tersebut di dalam operasionalnya melibatkan subsistemnya yang bekerja secara koheren, koordinatif dan integratif, agar dapat mencapai efesiensi dan efektivitas yang maksimal. Oleh karena itu efesiensi maupun efektivitasnya sangat tergantung pada faktor-faktor sebagai berikut: ${ }^{13}$

\footnotetext{
${ }^{12}$ Muladi, 1995.Kapita Selekta Sistem Peradilan Pidana, Semarang : Badan Penerbit UniversitasDiponegoro, hal. 79.

${ }^{13}$ Ibid, hal. 80 .
} 
a) Infrastruktur pendukung sarana dan prasarana;

b) Profesionalisme aparat penegak hukum dan;

c) Budaya hukum masyarakat

Terhadap masalah penegakan hukum Soerjono Soekanto mengemukakan bahwa secara konsepsional inti dan arti penegakan hukum terletak pada kegiatan menserasikan hubungan nilai-nilai yang terjabarkan didalam kaidah-kaidah yang mantap dan mewujudkan sikap tindak sebagai rangkaian penjabaran nilai tahap akhir, untuk menciptakan, memelihara dan mempertahankan kedamaian pergaulan hidup. Sebagai suatu proses penegakan hukum pada hakikatnya merupakan penerapan diskresi yang menyatakan pembuat keputusannya tidak secara ketat diatur oleh kaidah hukum. Sehubungan dengan pandangan di atas ada beberapa faktor yang mempengaruhi penegakan hukum yaitu:

a) Faktor hukumnya sendiri

b) Faktor penegak hukum

c) Faktor sarana atau fasilitas yang mendukung penegakan hukum

d) Faktor masyarakat

e) Faktor kebudayaan

Kelima faktor di atas merupakan faktor-faktor yang terkait satu sama lain merupakan esensi dari penegakan hukum dan bekerjanya hukum dalam masyarakat. Kaitannya dengan penegakan hukum terhadap delik perjudian, efesiensi maupun efektivitasnya juga tergantung kepada faktor-faktorsebagaimana disebutkan yang meliputi:

a) Faktor Perundang-Undangan

Meskipun eksistensi pengaturan delik perjudian tidak hanya dalam Undangundang Nomor 7 Tahun 1974 tentang Penertiban, tetapi juga terdapat di dalam KUHP. Namun masih terdapat bentuk-bentuk delik perjudian yang belum mendapatkan pengaturan, khususnya yang menyangkut penyalahgunaan teknologi canggih dalam melakukan judi.

Salah satu asas dalam hukum pidana menentukan (asas legalitas), bahwa tiada suatu perbuatan yang dilarang dan diancam dengan pidana jikalau bal itu terlebih dabulu belum dinyatakan dalam suatu aturan perundang-undangan.Maka pengaturan atas 
delik perjudian yang masih belum terakomodasi dalam perundang-undangan dimaksud sifatnya cukup penting.

Menurut Muladibahwa secara operasional perundang-undangan pidana mempunyai kedudukan strategis terhadap sistem peradilan pidana. Sebab hal tersebut memberikan defenisi tentang perbuatan-perbuatan apa yang dirumuskan sebagai tindak pidana. Mengendalikan usaha-usaha pemerintah untuk memberantas kejahatan dan memidana si pelaku, memberikan batasan tentang pidana yang dapat diterapkan untuk setiap kejahatan. Dengan perkataan lain perundang-undangan pidana menciptakan legislated environment yang mengatur segala prosedur dan tata cara yang harus dipatuhi di dalam pelbagai peringkat sistem peradilan pidana. ${ }^{14}$

b) FaktorPenegak Hukum

Keberhasilan misi hukum pidana untuk menanggulangi delik perjudian tidak hanya ditentukan oleh sempurnanya formulasi postulat hukum yang dirumuskan dalam hukum positif, melainkan keberhasilannya sangat tergantung kepada aparat yang melaksanakannya (penegak hukum); mulai dari tingkat penyidikan hingga tingkat eksekusi.Hal ini dikarenakan karakteristik yang khas dari delik perjudian sebagai suatu tindak pidana yang bersifat konvensional.Konsekuensi logisnya, aparat penegak hukum harus memiliki kemampuan lebih dan keberanian moral dalam menangani delik perjudian serta aparat penegak hukum dituntut sekaligus diuji untuk melakukan penemuan hukum (rechtvinding), sehingga tidak ada alasan klasik yang menyatakan dibalik asas legalitas sempit bahwa aturan perundangundangan tidak lengkap atau belum ada perundang-undangan yang mengaturnya.

c) Faktor Infrastruktur Pendukung Sarana Dan Prasarana

Faktor ini dapat dikatakan sebagai tulang punggung penegakan hukum terhadap delik perjudian.Sebab eksistensinya merupakan penopang keberhasilan untuk menemukan suatu kebenaran materiil. Jalinan kerjasama yang harmonis antara lembaga penegak hukum dengan beberapa pakar dan spesialis dibidangnya seperti ahli forensik, pakar telematika serta dana operasional yang memadai adalah

${ }^{14}$ Ibid, hal. 82. 
merupakan faktor pendukung guna menindak ataupun mempersempit ruang gerak pelaku delik perjudian.

d) Faktor Budaya Hukum Masyarakat

Tidak kalah penting dengan faktor-faktor yang lain, faktor budaya hukum masyarakat juga memiliki pengaruh dan memainkan peranan yang penting dalam proses penegakan hukum terhadap delik perjudian. Pluralisme budaya hukum di tengah masyarakat merupakan fenomena yang unik dan mengandung resiko yang potensial, sehingga seringkali menempatkan posisi dan profesi aparat penegak hukum ke dalam kondisi dilematis, yang pada gilirannya dapat menimbulkan ambivalensi dalam melaksanakan peranan dalam masyarakat.

Kepatuhan semua masyarakat terhadap hukum, ketidakdisiplinan sosial, tidak diindahkannya etika sosial, mudahnya anggota masyarakat tergiur oleh suatu bentuk perjudian yang menawarkan keuntungan diluar kelaziman dan lain sebagainya.Adalah sederetan contoh dari bentuk-bentuk budaya hukum yang rawan serta potensial untuk terjadinya delik perjudian.

Berdasarkan pendapat di atas, maka pembuatan peraturan perundangundangan harus dirumuskan secara jelas dan terinci mengatur dan memberi sanksi agar tidak menimbulkan keraguan dalam penerapannya serta tercipta suatu keadilan dan kepastian hukum bagi pihak-pihak yang berperkara.

Memperhatikan masalah penegak hukum ini jika dikaitkan dengan penegak hukum terhadap delik perjudian, maka aktivitas atau kegiatan yang dapat dilakukan sebagai upaya menghadapi masalah-masalah yang timbul dalam rangka penegakan hukum dan antisipasinya dapat meliputi pembuatan undang-undang atau penyempurnaan ketentuan yang sudah ada.Tersedianya aparat penegak hukum yang memadai baik secara kuantitas maupun secara perorangan maupun kelompok.

Berdasarkan uraian yang telah dipaparkan di atas dapat dilihat bahwa efektivitas fungsionalisasi hukum pidana terhadap delik perjudian tidak hanya terletak pada efesiensi dan efektivitas kinerja masing-masing sub sistem dalam peradilan pidana. Melainkan juga tergantung pada dukungan sosial maupun kelembagaan dalam rangka pembentukan opini masyarakat tentang delik perjudian dan sosialisasi hukum nasional secara luas. 


\section{Kebijakan Aplikatif Hukum Pidana Dalam Menanggulangi Tindak Pidana Perjudian}

Problema penegakan hukum di Indonesia nampaknya mulai menghadapi kendala berkaitan dengan perkembangan masyarakat yang kian cepat. Berbagai kasus menggambarkan sulitnya penegak hukum mencari cara agar hukum nampak sejalan dengan norma masyarakat. Bagaimana pun juga masalah perjudian, baik itu menguntungkan atau merugikan, tidak dapat dilepaskan dengan manusia dan perilakunya dalam kehidupan bermasyarakat.Judi adalah salah satu hasil karya dan rekayasa manusia dalam memenuhi kebutuhan hidupnya baik secara rohani maupun secara jasmaniah di tengah masyarakat yang penuh dengan persaingan dan krisis.

Perilaku berjudi juga merebak dalam masyarakat Indonesia.Namun karena hukum yang berlaku di Indonesia tidak mengijinkan adanya perjudian, maka kegiatan tersebut dilakukan secara sembunyi-sembunyi.Perjudian dalam masyarakat Indonesia dapat dijumpai di berbagai lapisan masyarakat. Bentukbentuk perjudian pun beraneka ragam, dari yang tradisional seperti togel (toto gelap/Singapura), perjudian dadu, sabung ayam, permainan ketangkasan, tebak lagu sampai pada penggunaan teknologi canggih seperti judi melalui telepon genggam atau internet. Perjudian online di internet pun sudah sangat banyak dikunjungi para penjudi, meskipun tidak diperoleh data apakah pengguna internet Indonesia sering browsing ke situs-situs tersebut.webstakes.comdan aceshigh.com merupakan dua nama situs judi online yang telah dikunjungi oleh jutaan pengunjung.

Lahirnya Undang-undang Nomor 7 Tahun 1974 tentang Penertiban Perjudian ini jelas menyatakan bahwa ancaman hukuman dalam KUHP untuk perjudian tidak sesuai lagi sehingga perlu diperberat. Bahkan, pasal pelanggaran judi dijadikan kejahatan dan hukumannya dinaikkan dari satu bulan menjadi empat tahun (Pasal 542 ayat (1), serta dari tiga bulan menjadi enam tahun (Pasal 542 ayat (2).Meski ancaman hukuman diperberat dan jenis tindak pidana diubah (dari pelanggaran menjadi kejahatan), tapi masalah patologi sosial ini masih belum tertanggulangi dengan baik. 
Dalam rangka menanggulangi tindak pidana perjudian perlu diimbangi dengan melakukan pembenahan dan pembangunan sistem hukum pidana secara menyeluruh dalam suatu bentuk kebijakan legislatif atau yang dikenal dengan kebijakan formulasi atau kebijakan criminal, sebagaimana dikemukakan pada bab terdahulu bahwa kebijakan kriminal merumuskan dan menetapkan sanksi pidana dalam perundang-undangan, dapat juga disebut sebagai tahap kebijakan formulasi. Kebijakan formulasi mempunyai posisi yang sangat strategis bila dipandang dari keseluruhan kebijakan mengoperasionalisasikan hukum pidana.Pada tahap ini dirumuskan garis kebijaksanaan sistem pidana dan pemidanaan yang sekaligus sebagai landasan legislatif bagi tahap-tahap berikutnya, yaitu tahap penerapan pidana oleh badan pengadilan dan tahap pelaksanaan pidana oleh aparat pelaksana pidana.

Berdasarkan pandangan di atas dapat disimpulkan bahwa kebijakan legislatif atau formulasi menempati posisi terpenting dari keseluruhan upaya mengoperasionalisasikan sanksi pidana.Di samping menjadi landasan bagi tahaptahap berikutnya juga menjadi landasan legalitas bagi kebijakan pemidanaan. Akan tetapi yang penting dari kebijakan formulasi ini yaitu sejauh mana posisi yang strategis dari kebijakan tersebut dapat mempengaruhi proses dan mekanisme penegakan hukum dalam upaya penanggulangan kejahatan khususnya delik perjudian.

Undang-Undang Nomor 7 Tahun 1974 Tentang Penertiban Perjudian tersebut merupakan bentuk perumusan dan penetapan sanksi pidana oleh pembentuk undang-undang.Sebagai kebijakan formulasi untuk kepentingan praktis bagi aparat penegak hukum dalam menangani permasalahan yang berkaitan dengan tindak pidana perjudian. Maksud lain dari pembentuk undang-undang dalam merumuskan ketentuan dasar mengenai penetapan masalah perjudian sebagai kejahatan dengan di dasari pemikiran perjudian adalah bertentangan dengan agama, kesusilaan, dan moral Pancasila, serta membahayakan bagi penghidupan dan kehidupan masyarakat, bangsa, dan negara.

Dengan adanya perubahan tersebut, ancaman pidana yang semula berupa kurungan maksimum satu bulan atau denda maksimum Rp. 4.500,00 dinaikkan menjadi pidana penjara maksimum empat tahun atau denda maksimum Rp. 
10.000.000,00 (sepuluh juta rupiah). Mengenai delik perjudian dimuat dalam ayat (1), sedangkan pada ayat (2) pengulangannya yang merupakan dasar pemberatan pidana.kejahatan dalam ayat (1) ada dua bentuk sebagaimana dirumuskan pada butir 1 dan 2, yaitu:

a. Melarang orang yang bermain judi dengan menggunakan kesempatan yang diadakan dengan melanggar pasal 303;

b. Melarang orang ikut serta bermain judi di tempat umum kecuali ada izin dari penguasa dalam hal untuk mengadakan perjudian itu.

Ikut serta bermain judi di sini adalah ikut serta yang lain dari Pasal 303. Pengertian perbuatan turut serta di sini adalah pengertian perbuatan turut serta (medeplegen) dalam arti sempit dari Pasal 55 ayat (1) butir 1 KUHP, di mana dua orang melakukan tindak pidana bersama-sama yang perbuatan mereka sama-sama memenuhi semua rumusan tindak pidana. Ukurannya ialah tanpa ada dua orang yang perbuatannya sama-sama memenuhi semua unsur di tempat umum.

Kejahatan bentuk pertama tidaklah disebutkan adanya unsur tanpa mendapat izin, karena menurut Pasal 303 perbuatan menawarkan kesempatan atau memberikan kesempatan bermain judi itu sendiri memang harus tanpa izin, sudah barang tentu orang yang menggunakan kesempatan yang diadakan menurut Pasal 303, juga dengan sendirinya sudah tanpa mendapat izin. Lain halnya dengan kejahatan bentuk kedua menurut Pasal 303 bis ini, harus disebutkan tanpa izin, walaupun rumusannya dengan kalimat yang lain yakni kecuali kalau ada izin. Sebab jika tidak ditambahkan unsur demikian, setiap bentuk permainan judi akan dijatuhi pidana, dan ini tidak sesuai dengan konsep perjudian menurut hukum (KUHP), sebab permainan judi hanya menjadi larangan apabila tanpa izin. Sifat melawan hukum permainan judi hanya menjadi larangan apabila tanpa izin.Memang konsep mengenai perjudian menurut KUHP berbeda dengan konsep menurut nilai-nilai yang hidup di masyarakat kita yang dipengaruhi norma-norma agama, di mana dalam hal perjudian itu dilarang dalam segala bentuknya, yang tidak digantungkan ada atau tidak adanya izin dari penguasa yang berwenang.Bahkan menurut agama, pejabat yang memberi izin perjudian itupun berdosa. 


\section{E. Penutup}

Kebijakan kriminal dalam menanggulangi tindak pidana perjudian diatur dalam Pasal 303 ayat (3) KUHP dan secara detil dijelaskan dalam penjelasan Pasal 1 Peraturan Pemerintah RI Nomor 9 Tahun 1981 tentang Pelaksanaan UndangUndang Nomor 7 Tahun 1974 tentang Penertiban Perjudian. Antara lain adalah rolet, poker (main kartu), hwa-hwe, nalo, adu ayam, adu sapi, adu kerbau, adu kambing, pacuan kuda dan karapan sapi.Kebijakan aplikatif hukum pidana dalam menanggulangitindak pidana perjudian di Indonesia yaitu tindak pidana perjudian, hakim tidak memiliki kebebasan dalam menentukan jenis-jenis pidana yang sesuai untuk pelaku tindak pidana dan harus menerapkan atau menetapkan ketentuan ancaman pidana yang telah disediakan dalam peraturan perundang-undangan.

\section{DAFTAR PUSTAKA}

Barda Nawawi Arief, 1996. Kebijakan legislatif dalam Penanggulangan Kejahatan dengan Pidana Penjara, Semarang : Balai penerbitan Undip.

Bolmer Suryadi Hutasoit, 2011. Telaah dan Analisis Perjudian dariSisi Kriminologi. Diakses di http://bolmerhutasoit.wordpress.com/2011/08/15/makalah-kriminologitelaah-dan-analisis-perjudian-dari-sisi-kriminologi/ pada tanggal 21 September 2011.

Dwidja Priyatno, 2004. Kebijakan Legislasi Tentang Sistem Pertanggungjawaban Pidana Korporasi di Indonesia. Bandung : CV. Utomo.

Eva Achjani Zulfa, 2007. Ketika Jaman Meninggalkan Hukum, diakses di http://sukirman.weebly.com/1/post/2011/03/ketika-jamanmeninggalkan-hukum.html pada tanggal 22 September 2011

Kartini Kartono, 2005. Patologi Sosial. Jakarta : Raja Grafindo Persada.

Muladi, 1995.Kapita Selekta Sistem Peradilan Pidana, Semarang : Badan Penerbit Universitas Diponegoro , 2007.Masalah Penegakan Hukum Dan Kebijakan Hukum Pidana Dalam Penanggulangan Kejahatan, Jakarta : Kencana.

Muladi dan Barda Nawawi Arief, 1998.Teori-Teori dan Kebijakan Pidana, Cet. II, Bandung : Penerbit Alumni.

Nyoman Serikat Putra Jaya, 2005. Relevansi bukum pidana adat dalam pembaharuan bukum pidana nasional.Bandung: Citra Aditya Bakti.

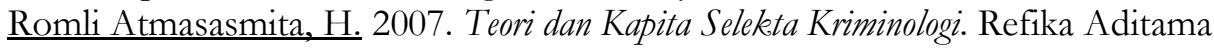

Ronny Hanitijo Soemitro, 1985. Beberapa Masalah Dalam Studi Hukum dan Masyarakat.Bandung : Remaja Karya.

Rusli Effendy, 1986. Azas-azas Hukum Pidana.Makassar : LEPPEN-UMI.

Simandjuntak, B, 1980. Pengantar Kriminologi dan Patologi Sosial, Bandung: Tarsito. 
Soerjono Soekanto \& Sri Mamudji, 1985.Penelitian bukum normatif: suatu tinjauan singkat. Jakarta : Rajawali

Soesilo, R. 1996. Kitab Undang-Undang Hukum Pidana (KUHP) serta KomentarKomentarnya Lengkap Pasal Demi Pasal.Bogor : Politea.

Syamsuddin Adz-Dzahabi. 1992. 75 Dosa Besar. Surabaya: Media Idaman 